Boterbloem, Kees. "Deák, István. 2015. Europe on Trial: The Story of Collaboration, Resistance and Retribution during World War II. Boulder: Westview Press. 257 pp. with maps and photographs." Hungarian Cultural Studies. e-Journal of the American Hungarian Educators Association, Volume 8 (2015): http://ahea.pitt.edu DOI: 10.5195/ahea.2015.194

\title{
Deák, István. 2015. Europe on Trial: The Story of Collaboration, Resistance and Retribution during World War II. Boulder: Westview Press. 257 pp. with maps and photographs.
}

\section{Reviewd by Kees Boterbloem}

The eminent Hungarian-American historian István Deák has delivered one of his finest works with this book that problematizes what once seemed a deceptively simple history of the Second World War. In a lucid manner and an admirably brief fashion, Deák's work offers a comprehensive account of the "collaboration, accommodation, resistance, and retribution" of all European countries [excluding Ireland] during this bloodiest chapter of human history" (11). Deák's book in a way even surpasses the chilling account of Timothy Snyder's Bloodlands Europe between Hitler and Stalin (New York: Basic Books, 2010) that covered the savagery before, during and after the war in northern and Central-Eastern Europe, wherein much of the worst butchery unfolded. As Deák shows, however, no part of Europe kept clean hands, heroically championing the cause of democracy and human rights and freedom, and protecting people from evil. Even the British citizens of the Channel Islands come in for a lambasting in their wholesale collaboration with the Nazis. And the bloodshed in the Kingdom of Yugoslavia or in Hungary was proportionally hardly less than in the Soviet Union or Poland in the era of Nazi hegemony and during the subsequent German retreat from these countries. Deák questions the hagiography about the resistance movements in many German-occupied European countries by arguing that their acts of resistance were illegitimate according to formal legal theory, while their worth was in practice dubious as their retribution measures usually cost many more lives (such as those of executed hostages) among the civilian population than the initial deed had cost the German occupying forces, or their fanatical local allies.

A Hungarian native of partial Jewish extraction, István Deák (b. 1926) was a teenager during the war and escaped Soviet-ruled Hungary in 1948. His charting of the complications of the Nazi-triggered tragedy that engulfed Europe between 1938 and 1945 has therefore the enhanced quality of someone who witnessed the events unfolding. He was personally confronted with the twists-and-turns of Admiral Horthy's regime in its effort to keep the Germans at bay, and of the dreadful end of the war, when massive numbers of Hungarian Jews (who had been partly shielded by Horthy until then) were now dispatched to Auschwitz during the brief reign of the Arrow-Cross dictatorship led by Ferenc Szálasi and propped up by German military force.

Deák's would-be brother-in-law (his sister's fiancé) was killed by the Arrow-Cross militia in a gunfight in late 1944. Thus Deák, too, observed the hypocrisy about the war that became the norm in the postwar period, when every European country (including, most notoriously, Austria) began to claim to have been a victim of Nazism, with the great majority of its population allegedly aiding-and-abetting (or actively participating in) the resistance against the Germans. Ironically, this tale prevailed on both sides of the Iron Curtain: following a brief period of taking revenge on Germans and their collaborators in the early postwar era, the collaboration was downplayed and the heroics of the resistance was played up. In reality, as Deák writes, "German

$($ (c) $)$ EY

ULIS D-Senk 
Boterbloem, Kees. "Deák, István. 2015. Europe on Trial: The Story of Collaboration, Resistance and Retribution during World War II. Boulder: Westview Press. 257 pp. with maps and photographs." Hungarian Cultural Studies. e-Journal of the American Hungarian Educators Association, Volume 8 (2015): http://ahea.pitt.edu DOI: 10.5195/ahea.2015.194

soldiers and policemen were numerous enough to rule the [occupied] land but not enough to control every town, village, and forest. As a consequence, national governments, local authorities, native populations, and diverse social classes and interest groups, as well as many individuals, were eager, for myriad reasons, to tolerate the inevitable presence of, actively collaborate with, or oppose the ruling Germans" (1). As for the trigger and timing of opposition, at several points in his study Deák reiterates that it was only after the German surrender at Stalingrad in February 1943 that the ranks of the resistants really began to swell in most countries.

Deák does note, though, that anti-German resistance in the occupied zones of the Soviet Union was substantial right from the beginning, because the Germans showed no mercy to the Slavic untermenschen or the "Jewish vermin" residing in Belarus, Ukraine and western Russia. German captivity for Soviet soldiers was tantamount to a death sentence (with Soviet POWs serving as guinea pigs to test the gas chambers in Auschwitz), and joining the brutal partisan warfare in the forests at least offered a chance of survival. As Deák reminds us, the Nazis missed a golden opportunity by their brutal behavior in the East: had they treated the population of the conquered territories as correctly as they treated the Danes, French, Norwegians or Dutch, they might have found or created a receptive audience among them and then Stalin's post-war regime would have found it impossible to reestablish itself in Ukraine or Belarus. And even then the guerilla war in Soviet Ukraine against the Soviets only abated toward 1950.

With a few exceptions, such as Colonel Claus von Stauffenberg who led the failed plot against Hitler's rule, the Germans are not spared either in Deák's account: a rare few of them resisted the Nazis, and too many ordinary soldiers and S.S. men engaged in savage "crimes against humanity," a new category of crime introduced by the postwar Nuremberg Trials. These trials were themselves highly flawed proceedings, as Deák points out, but at least they set the table for the prosecution of future war criminals. Toward the end of his study Deák concludes: "One might ask, referring to the title of this book, how well Europe on trial passed the test of the troubled times. The answer is, unfortunately, that Europe did badly" (225). Indeed, he amply proves his case that the war and its crises amounted to a "European-wide crisis in compassion and humanity" (226).

Altogether, this book may very well become a classic as the standard textbook regarding issues of resistance versus collaboration in Europe of the Nazi-era. It is eminently well suited for almost any course on Second World War and can just as well be used in courses on twentiethcentury European history, or as a prehistory in courses on the European-Unity project. The volume's maps and suggested readings are excellent and stimulate further research by novices. It is to be hoped, however, that this book reaches a far broader audience than that of college or university researchers and students, as it is a magnificent treatment of "civilian life" in the Second World War. 